Ekspansi: Jurnal Ekonomi, Keuangan, Perbankan dan Akuntansi

ISSN (Online): 2580-7668 ISSN (Print): 2085-5230

Vol. 11, No. 1 (Mei 2019), Hal. 117 - 128

\title{
PENGARUH BELANJA KESEHATAN DAN ANGKA KEMISKINAN TERHADAP ANGKA HARAPAN HIDUP KABUPATEN KOTA DI JAWA BARAT
}

\author{
Estro Dariatno Sihaloho ${ }^{1}$, Donny Hardiawan ${ }^{2}$ \\ ${ }^{1,2}$ Departmen Ilmu Ekonomi, Fakultas Ekonomi dan Bisnis Universitas Padjadjaran, \\ Sumedang, Indonesia \\ Email Korespondensi: estro.sihaloho@unpad.ac.id
}

\begin{abstract}
This paper has two objectives. The first is to estimate the effect of health expenditure on life expectancy in regencies and cities in West Java Provinces. The second is to estimate the effect of the number of poor people on life expectancy in regencies and cities in West Java Provinces. Life expectancy is a measurement of the average time of human lives. This paper uses three-technique of Data Panel regression model: Pooled OLS, Fixed Effect Model and Random Effect Model. This paper uses Data Panel on 27 Regencies and Cities in West Java Provinces from 2014 to 2016. This paper use Life expectancy as the dependent variable, health expenditure and number of poor people as the independent variable. The result shows that Pooled OLS, Fixed Effect Model and Random Effect Model estimate the health expenditure has a positive and significant effect on life expectancy in regencies and cities in West Java Provinces. Pooled OLS and Random Effect Model technique estimate number of poor people has a negative and significant effect on life expectancy in regencies and cities in West Java Provinces.
\end{abstract}

Keywords: Life Expectancy, Health Expenditure, Poverty

Abstrak: Penelitian ini memiliki dua tujuan. Tujuan pertama adalah untuk mengestimasi pengaruh belanja kesehatan terhadap angka harapan hidup (AHP) Kabupaten Kota di Jawa Barat. Tujuan kedua adalah untuk mengestimasi bagaimana pengaruh total kemiskinan terhadap angka harapan hidup (AHP) Kabupaten Kota di Jawa Barat. Angka harapan hidup adalah pengukuran ekspektasi rata-rata umur manusia. Penelitian ini menggunakan tiga pendekatan regresi model Data Panel yaitu Pooled OLS, Fixed Effect Model dan Random Effect Model. Penelitian ini menggunakan Data Panel pada 27 Kabupaten Kota di Jawa Barat pada tahun 2014 hingga tahun 2016. Penelitian ini menggunakan angka harapan hidup (AHP) sebagai variabel dependen, variabel belanja kesehatan dan total kemiskinan sebagai variabel independen. Hasil menunjukkan Pooled OLS, Fixed Effect Model dan Random Effect Model menunjukkan bahwa belanja kesehatan memiliki pengaruh positif dan signifikan pada angka harapan hidup Kabupaten Kota di Jawa Barat. Teknik regresi Pooled OLS dan Random Effect Model menunjukkan bahwa total kemiskinan memiliki pengaruh negatif dan signifikan pada angka harapan hidup Kabupaten Kota di Jawa Barat.

Kata Kunci: Angka Harapan Hidup, Anggaran Kesehatan, Kemiskinan

DOI: $10.35313 /$ ekspansi.v11i1.1308

Riwayat Artikel:

Diterima: $24-3-2019$

Direvisi: $12-5-2019$

Disetujui: 20 - $5-2019$ 


\section{PENDAHULUAN}

Kesehatan menjadi factor yang sangat penting dalam pembangunan dan pertumbuhan ekonomi sebuah negara. Tujuan dari pembangunan yang berkelanjutan tidak akan dapat di capai apabila terdapat prevalensi penyakit yang tinggi di dalam sebuah negara (Boyacioglu, 2012). Untuk mengatasi prevalensi penyakit, maka negara perlu memperkuat sistem kesehatan. Negara sulit memiliki sistem kesehatan terbaik karena adanya keterbatasan anggaran, keterbatasan infrastruktur kesehatan, dan keterbatasan sumber daya manusia di sektor kesehatan (Lakshminarayanan, 2011). Pemerintah perlu meningatkan tingkat belanja sektor kesehatan sehingga banyak masalah kesehatan bisa diatasi. Penelitian sebelumnya menunjukkan bahwa terdapat hubungan yang positif dan signifikan antara belanja kesehatan dengan pertumbuhan ekonomi (Piabuo \& Tieguhong, 2017). Hal ini disebabkan karena pada umumnya, masyarakat dengan tingkat kesehatan yang baik dapat memproduksi barang dan jasa yang lebih banyak di bandingkan masyarakat dengan tingkat kesehatan buruk, yang mendorong pertumbuhan ekonomi yang lebih cepat (Wang, 2015).

Pemerintah Indonesia membutuhkan biaya yang sangat besar untuk membiayai seluruh sistem kesehatan. Pembiayaan ini berasal dari berbagai sumber baik dari pemerintah pusat maupun dari pemerintah daerah (Dewi, 2017). Kebijakan otonomi daerah yang diterapkan pemerintah pusat membawa perubahan pada anggaran kesehatan di Indonesia (Harmana \& Adisasmito, 2006). Dengan ada nya otonomi, kebijakan yang diambil oleh masing-masing pemerintah Kabupaten Kota di Jawa Barat juga berbeda. Berikut adalah gambar yang menggambarkan total belanja Kabupaten Kota di Jawa Barat dari tahun 2015 hingga tahun 2016.

Gambar 1. Total Anggaran Kesehatan Kabupaten Kota di Jawa Barat 2015-2016

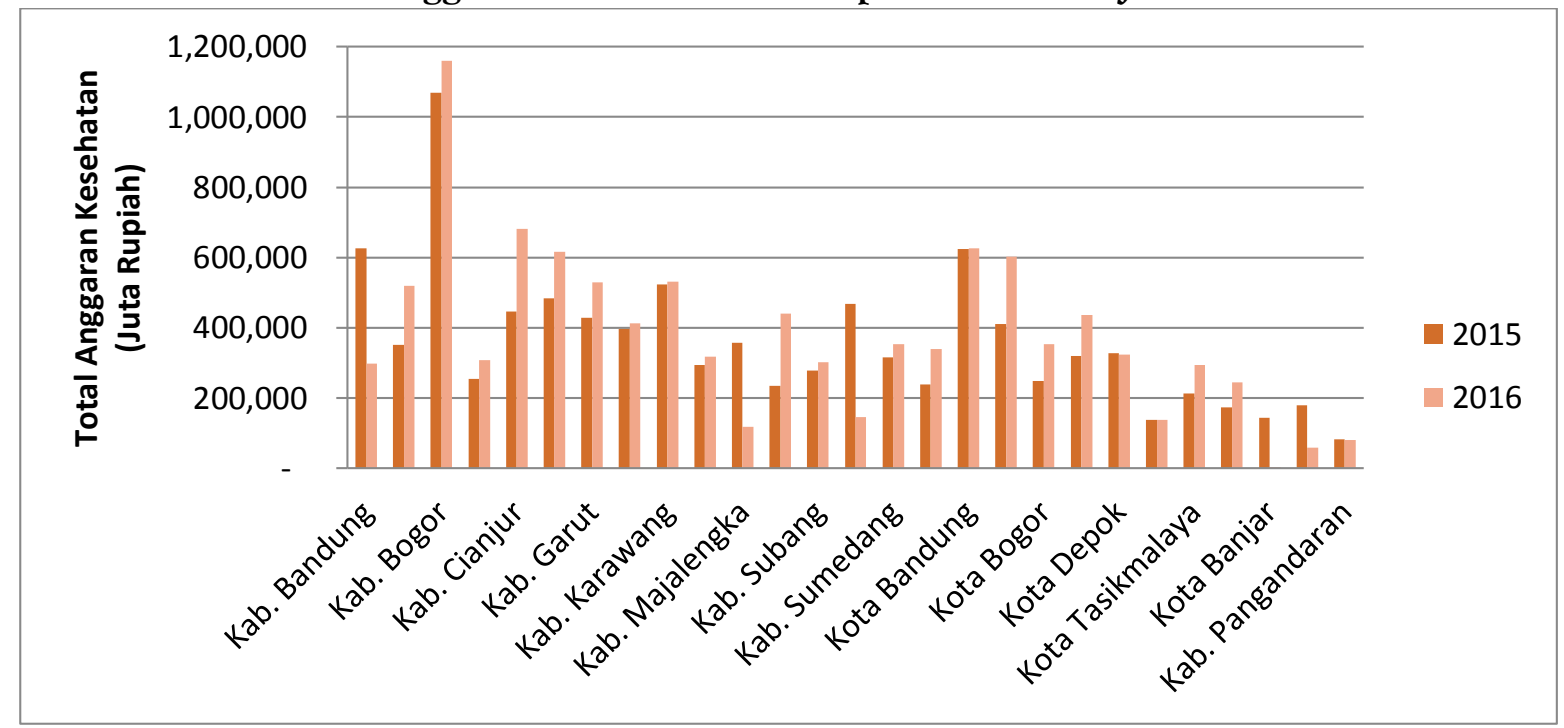

Sumber : (Directorate General of Fiscal Balance of Indonesia, 2016)

Gambar 1 menunjukkan bahwa hampir semua pemerintah Kabupaten Kota di Jawa Barat meningkatkan jumlah anggaran kesehatan. Hanya ada beberapa daerah yang mengalami penurunan anggaran kesehatan seperti Kabupaten Bandung, Kabupaten Majalengka, Kabupaten Sukabumi, Kota Depok, Kota Banjar, Kabupaten 
Bandung Barat, dan Kabupaten Pangandaran. Dengan anggaran yang ada, menjadi sebuah pertanyaan apakah masing-masing pemerintah dapat mendapatkan output kesehatan yang maksimal atau tidak.

Angka Harapan Hidup atau life expectancy at birth merupakan indikator yang paling sering digunakan untuk melihat output dari pembangunan kesehatan. Penelitian sebelumnya menunjukkan bahwa terdapat hubungan yang signifikan antara belanja kesehatan dengan angka harapan hidup (Jaba, Balan, \& Robu, 2014). Berikut adalah gambar yang menunjukkan bagaimana output kesehatan Kabupaten Kota di Jawa Barat dari tahun 2015 hingga tahun 2016.

Gambar 2. Angka Harapan Hidup Kabupaten Kota di Jawa Barat 2015-2016

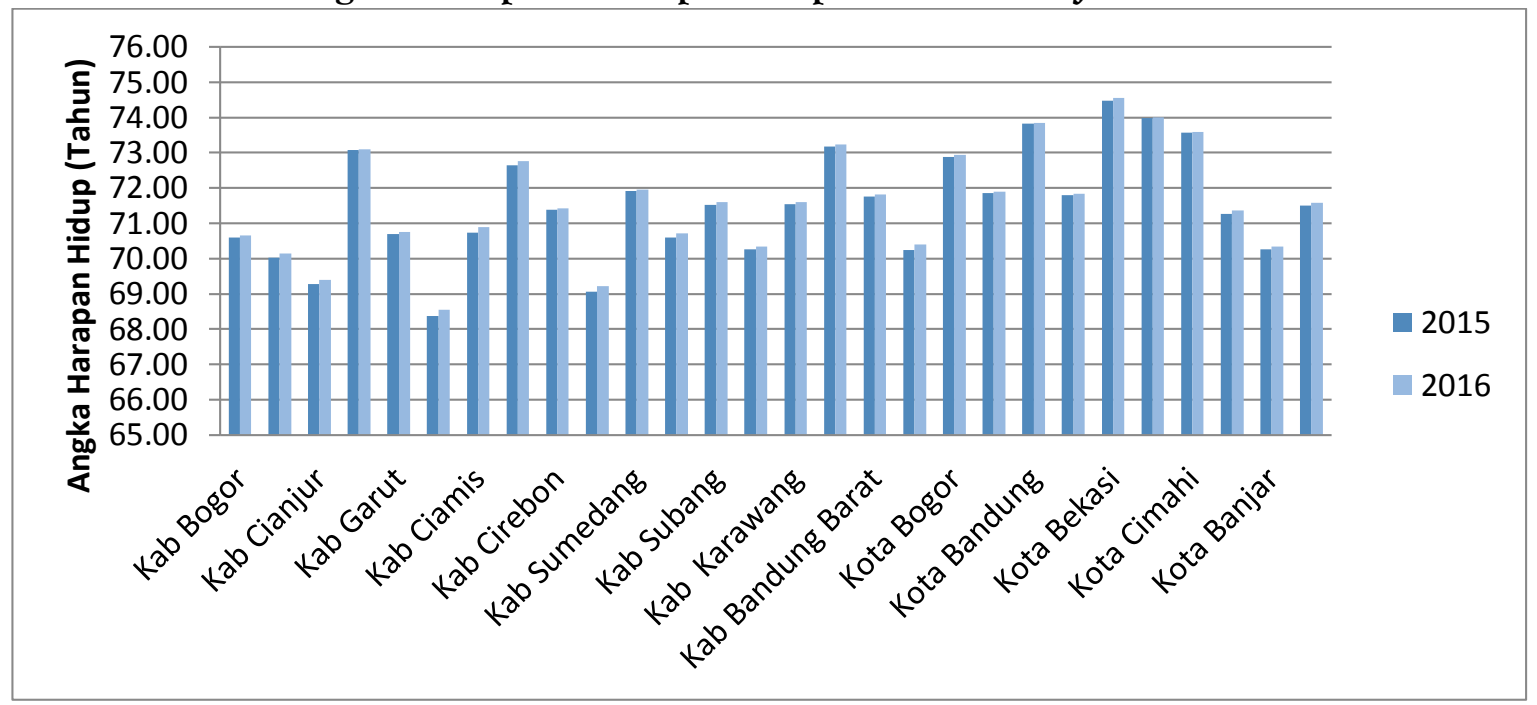

Sumber : (BPS Jawa Barat, 2017)

Gambar di atas menunjukkan bahwa Angka Harapan Hidup Provinsi Jawa Barat mengalami peningkatan dari tahun 2015 ke tahun 2016 tetapi tidak signifikan. Gambar 2 menunjukkan bahwa semua daerah Kabupaten Kota di Jawa Barat memiliki peningkatan Angka Harapan Hidup dari tahun 2015 ke tahun 2016. Peningkatan AHP terbesar terdapat pada Kabupaten Tasikmalaya sebesar 0.18 dan paling rendah adalah Kota Cimahi dengan peningkatan hanya sebesar 0.01. Pada tahun 2016, hanya terdapat 8 daerah Kabupaten Kota yang memiliki Angka Harapan Hidup lebih tinggi dibandingkan dengan Angka Harapan Hidup Provinsi Jawa Barat, sedangkan 19 daerah Kabupaten Kota lainnya lebih rendah.

Gambar 3 menunjukkan total anggaran kesehatan dan angka harapan hidup kabupaten kota di Jawa Barat pada tahun 2015 dan 2016. Gambar 3 menunjukkan terdapat daerah yang mengalami peningkatan anggaran kesehatan yang tinggi tetapi menghasilkan peningkatan angka harapan hidup yang rendah seperti Kabupaten Bogor (3), Kabupaten Cianjur (5), Kota Bekasi (18), dan daerah lainnya. Gambar 3 juga menunjukkan terdapat daerah yang meningkatkan anggaran kesehatan yang tidak sebesar Kabupaten Bogor (3), Kabupaten Cianjur (5), Kota Bekasi (18) tetapi mengalami peningkatan angka harapan hidup yang lebih tinggi seperti Kabupaten Ciamis (4) dan Kabupaten Tasikmalaya (16). Total anggaran kesehatan dan angka 
harapan hidup kabupaten kota di Jawa Barat pada tahun 2015 dan 2016 menunjukkan hubungan yang positif, tergantung bagaimana pemerintah mengelola anggaran kesehatan dan mengontrol faktor lain yang mungkin berpengaruh positif atau negatif terhadap tingkat kesehatan.

Gambar 3. Total Anggaran Kesehatan dan Angka Harapan Hidup Kabupaten Kota di Jawa Barat 2015-2016

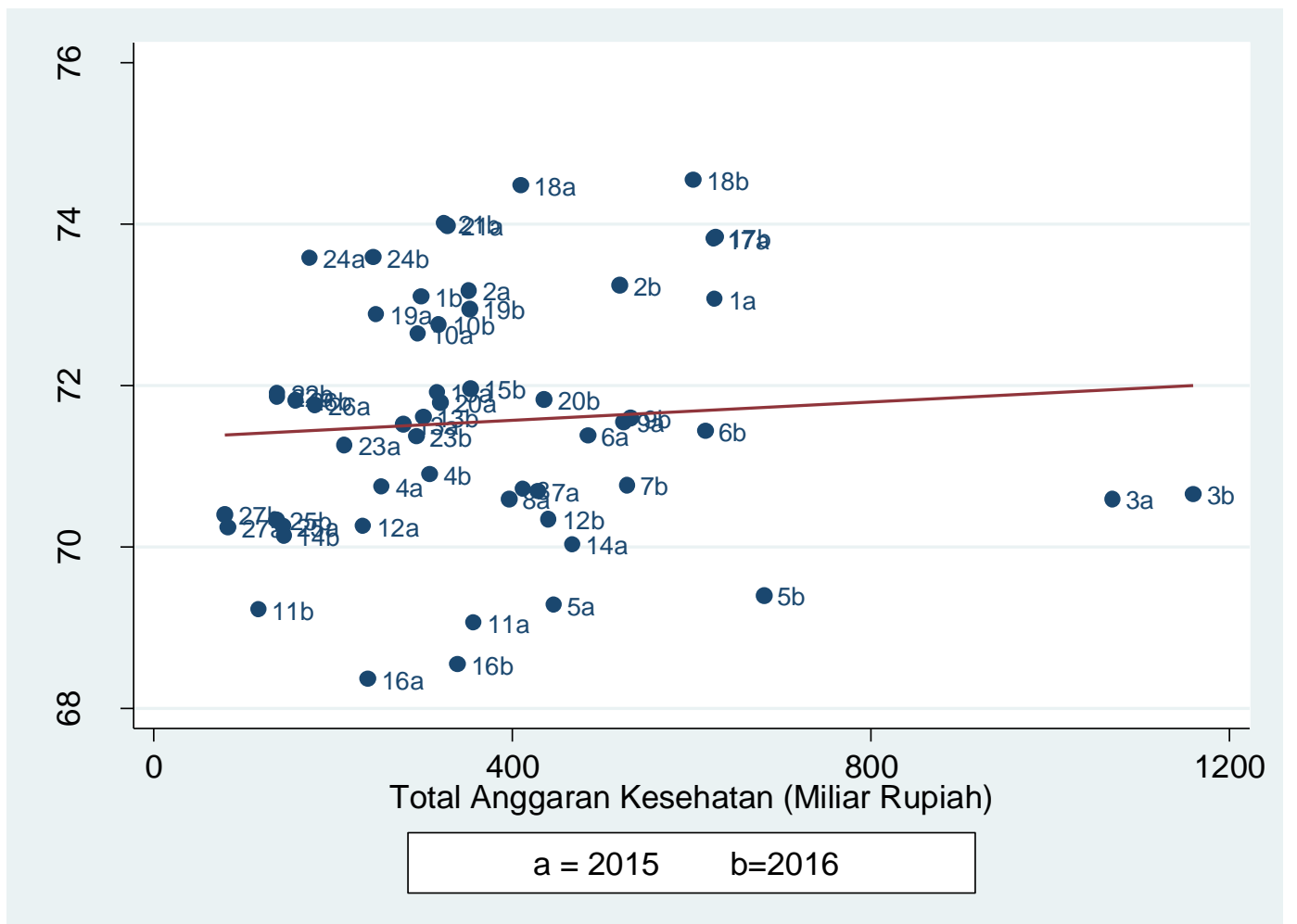

Sumber : (BPS Jawa Barat, 2017)

Pada tahun 2016, hampir semua Kabupaten Kota di Jawa Barat mengalami penurunan angka kemiskinan, hanya ada 3 daerah yang memiliki peningkatan kemiskinan seperti Kabupaten Bogor, Kota Depok, dan Kota Cimahi. Kabupaten bogor memiliki peningkatan kemiskinan paling tinggi yaitu sebesar 3,7 Ribu orang. Penurunan kemiskinan terjadi pada 24 daerah Kabupaten Kota lainnya. Penurunan paling tinggi terjadi di Kabupaten Garut sebesar 27 Ribu orang diikuti oleh Kabupaten Cirebon sebesar 24 Ribu orang. Dari sisi pertumbuhan penduduk, semua daerah Kabupaten Kota di Jawa Barat mengelami peningkatan. Pengingkatan jumlah penduduk paling tinggi terjadi di Kabupaten Bogor dengan peningkatan sebesar 127 Ribu orang, diikuti oleh Kabupaten Bekasi dengan peningkatan sebesar 125 Ribu orang. Peningkatan jumlah penduduk paling rendah terjadi di Kota Banjar dengan peningkatan hanya sebesar 476 orang.

Penelitian ini bertujuan untuk menganalisis bagaiamana pengaruh dari belanja kesehatan terhadap angka harapan hidup kabupaten kota di Jawa Barat. Penelitian ini juga melihat pengaruh faktor lain seperti angka kemiskinan dan total populasi terhadap angka harapan hidup kabupaten kota di Jawa Barat. Penelitian ini bisa 
menjadi rujukan bagaimana kabupaten kota di Jawa Barat dalam meningkatkan anggaran kesehatan untuk meningkatkan kualitas kesehatan masyarakat kabupaten kota di Jawa Barat.

\section{TINJAUAN PUSTAKA}

Hubungan antara kesehatan dengan pembangunan yang berkelanjutan dipaparkan dengan jelas di Deklarasi Rio pada tahun 1992. Kesehatan menjadi cara mengukur tingkat kemajuan dari pembangunan yang berkelanjutan (Boyacioglu, 2012). Kesehatan dapat menjadi stok kapital masyarakat sehingga memiliki pengaruh yang sangat menguntungkan bagi pembangunan (Musgrove, 1993). Kesehatan adalah sumber langsung dari kesejahteraan manusia dan juga menjadi sebuah instrumen untuk meningkatkan level pendapatan (Bloom David \& Canning, 2008). Dengan tingkat kesehatan yang baik akan meningkatkan produktifitas di dalam membangun perekonomian (Arora, 2002). Belanja pemerintah bidang kesehatan tidak memiliki hubungan jangka pendek dengan pertumbuhan ekonomi, tetapi memiliki hubungan jangka panjang (Boussalem, Boussalem, \& Taiba, 2014).

Kesehatan menjadi sektor yang memiliki anggaran besar di banyak negara maju (Borghini et al., 2017). Dengan anggaran besar, negara-negara maju dapat menggunakan anggaran dengan efisien untuk mengatasi banyak permasalahan kesehatan. Pengeluaran kesehatan menjadi penting karena memiliki pengaruh yang signifikan terhadap output kesehatan seperti mengurangi tingkat kematian dan meningkatkan angka harapan hidup (Arthur \& Oaikhenan, 2017). Penelitianpenelitian lainnya juga menunjukkan adanya hubungan antara belanja kesehatan dengan angka harapan hidup (Akca, Sönmez, \& Yllmaz, 2017; Sghari \& Hammami, 2016). Belanja pemerintah bidang kesehatan juga memiliki efek yang signifikan dalam mengurangi kematian bayi dan anak dan besar koefisien pengaruhnya tergantung pada kualitas pemerintah menggunakan anggaran tersebut (Farag et al., 2013). Dengan meningkatnya kualitas kesehatan, maka akan mendorong tingginya produktivitas penduduk. Dengan rendahnya tingkat kematian akan mengurangi kerugian dalam sebuah perekonomian.

Selain dipengaruhi oleh besarnya anggaran kesehatan, terdapat faktor-faktor lain yang bisa mempengaruhi efektifitas penggunaan anggaran dalam mencapai output kesehatan yang maksimal. Faktor tersebut adalah kemiskinan.Kemiskinan juga berpengaruh buruk terhadap output kesehatan di dalam sebuah negara. Masyarakat yang miskin cenderung memiliki angka harapan hidup yang lebih rendah karena masyarakat yang miskin cenderung memiliki keterbatasan perawatan kesehatan preventif (Torpy, Lynm, \& Glass, 2007).

Terdapat banyak penyakit menular pada masyarakat yang miskin, kondisi ibu hamil yang buruk dan kondisi anak yang kekurangan gizi (Ngoma, 2017). Lebih lanjut, kemiskinan mempengaruhi kesehatan anak-anak tidak hanya ketika mereka masih muda, tetapi juga di kemudian hari dalam kehidupan mereka sebagai orang dewasa (Gupta, de Wit, \& McKeown, 2007). Tingginya angka kemiskinan di akibatkan adanya pertumbuhan penduduk yang cepat. Tingkat pertumbuhan populasi yang tinggi 
berdampak pada tingginya masalah kesehatan (Taylor, Newman, \& Kelly, 1976). Tingginya pertumbuhan penduduk akan menjadikan belanja kesehetan per kapita dalam sebuah perekonomian menjadi lebih kecil. Dengan belanja kesehatan per kapita yang lebih rendah menjadikan sistem kesehatan tidak dapat berjalan maksimal.

\section{METODE PENELITIAN}

Penelitian ini menggunakan metode penelitian model regresi Data Panel. Model Data Panel digunakan dengan kombinasi data deret waktu dan lintas unit (Greene, 2012). Penggunaan model Data Panel adalah salah satu cara untuk meningkatkan spesifikasi dan estimasi model (Puron-cid, 2014). Gujarati (2003) memaparkan bahwa terdapat 2 teknik dalam regresi model Data Panel yaitu Model Efek Tetap (Fixed Effect) dan Model Efek Random (Random Effect) (Gujarati, 2003). Dalam penelitian lain, terdapat teknik yang digunakan dalam mengestimasi parameter pada data panel yaitu Koefisien Tetap Antar Waktu dan Individu (Pooled OLS) (Puron-cid, 2014). Pada umumnya, model Data Panel akan lebih efektif untuk meningkatkan ukuran sampel, mengoreksi autokorelasi, mengoreksi heteroskedastisitas, permasalahan standar eror, dan permasalahan derajat kebebasan (Puron-cid, 2014). Dalam Penelitian ini, ketiga teknik ini digunakan dalam regresi Data Panel.

Penelitian ini mengunakan data sekunder dari BPS Jawa Barat dari tahun 2014 hingga tahun 2016. Data yang digunakan adalah data 27 kabupaten kota yang ada di Provinsi Jawa Barat. Model Ekonometrik yang digunakan dalam penelitian ini adalah sebagai berikut:

Dimana:

$$
\mathrm{AHP}=\boldsymbol{\alpha}_{1}+\boldsymbol{\alpha}_{2} \text { AngKes }_{\text {it }}+\boldsymbol{\alpha}_{3} \text { TotMis }_{\text {it }}+\mathrm{U}_{\mathrm{it}}
$$

AHP : : merupakan Angka Harapan Hidup (Tahun)

AngKes : : merupakan Total Belanja Pemerintah Bidang Kesehatan

TotMis : : merupakan Total Kemiskinan

U : merupakan Error

\section{HASIL DAN PEMBAHASAN}

\subsection{Hasil Penelitian}

Berdasarkan data yang dikumpulkan dari tahun 2014 hingga tahun 2016, kemudian di dapatkan hasil deskripi statistik angka harapan hidup, total belanja pemerintah bidang kesehatan, total kemiskinan, total populasi 27 Kabupaten Kota di Provinsi Jawa Barat sebagai berikut :

Tabel 1. Tabel Deskripsi Statistik

\begin{tabular}{|l|c|c|c|c|c|}
\hline \multicolumn{1}{|c|}{ Variabel } & Obs & Mean & Std. Dev. & Min & Max \\
\hline AHP (Tahun) & 81 & 71.47 & 1.57 & 67.96 & 74.55 \\
\hline AngKes (Miliar Rupiah) & 81 & 340 & 199 & 47.143 & 1,160 \\
\hline TotMis (Ribuan) & 81 & 159.74 & 108.31 & 12.70 & 490.80 \\
\hline
\end{tabular}

Sumber : (BPS Jawa Barat, 2017) 
Dari tabel 1 di atas ditunjukkan bahwa jumlah observasi adalah sebanyak 81. Nilai minimum dari Angka Harapan Hidup (AHP) adalah 76.96 tahun, nilai maksimum adalah 74.55 tahun, nilai rata-rata sebesar 71.47 tahun dengan standar deviasi sebesar 1.57 tahun. Nilai minimum dari anggaran kesehatan yang di keluarkan pemerintah daerah adalah sebesar 47 Miliar Rupiah, nilai maksimum sebesar 1,160.08 Miliar Rupiah, nilai rata-rata sebesar 340 Miliar Rupiah dengan standar deviasi sebesar 199 Miliar Rupiah. Nilai minim total kemiskinan adalah sebesar 12 ribu orang, nilai maksimum sebesar 490 ribu orang, nilai rata-rata sebesar 159 ribu dengan standar deviasi sebesar 108 ribu orang.

Regresi Data Panel pada penelitian ini menggunakan tiga teknik yaitu Model Koefisien Tetap Antar Waktu dan Individu (Pooled OLS), Model Efek Tetap (Fixed Effect) dan Model Efek Random (Random Effect). Berikut adalah hasil regresi dengan ketiga teknik tersebut:

Tabel 2. Hasil Regresi Data Panel

\begin{tabular}{llll}
\hline Variabel & Pooled OLS & Fixed Effects Model & Random Effects model \\
\hline Anggaran Kesehatan & $0.004677^{* * *}$ & $0.000718^{* * *}$ & $0.004677^{* * *}$ \\
& 4.14 & 3.49 & 4.35 \\
\hline Total Kemiskinan & $-0.009914^{* * *}$ & -0.003713 & $-0.009914^{* * *}$ \\
& -5.08 & -1.11 & -5.02 \\
\hline Konstanta & 71.46158 & 71.81915 & 71.46158 \\
& 240.25 & 131.53 & 234.3
\end{tabular}

Level Signifikan: * untuk 10\%, ${ }^{* *}$ untuk 5\%, ${ }^{* *}$ untuk $1 \%$

Di adaptasi dari (Puron-cid, 2014)

Berdasarkan tabel 2 berikut adalah persamaan ekonometrik dalam regresi Data Panel 27 Kabupaten Kota di Jawa Barat Tahun 2014-2016:

a. Pooled OLS

\section{$\mathrm{AHP}=71.46158+0.004677$ AngKes - 0.009914 TotMis}

Regresi menggunakan Pooled OLS menunjukkan bahwa setiap anggaran kesehatan meningkat sebesar 1 Miliar Rupiah, maka angka harapan hidup akan bertambah sebesar 0.004677 , cateris paribus. Variabel TotMis menunjukkan bahwa setiap ada kenaikan seribu masyarakat miskin di daerah kabupaten kota di Jawa Barat akan menurunkan angka harapan hidup sebesar 0.009914, cateris paribus. Dengan menggunakan teknik pooled OLS, kita mendapatkan bahwa anggaran kesehatan berpengaruh signifikan terhadap angka harapan hidup sedangkan total kemiskinan tidak berpengaruh signifikan. Standar error pada Model Pooled OLS telah di robust sehingga terhindar dari masalah heteroskedastisitas. F stat pada regresi Pooled OLS adalah sebesar 13.01 dan nilainya signifikan. $\mathrm{R}^{2}$ pada regresi Pooled OLS adalah sebesar 0.2467 yang menunjukkan angka harapan hidup dipengaruhi variabel anggaran kesehatan dan variabel total kemiskinan dapat menjelaskan sebesar 24,67\% sedangkan sisanya $75.33 \%$ dipengaruhi faktor diluar model regresi. 
b. Fixed Effects Model

\section{$\mathrm{AHP}=71.81915+0.000718$ AngKes -0.003713 TotMis}

Regresi menggunakan Fixed Effects Model menunjukkan bahwa setiap anggaran kesehatan meningkat sebesar 1 Miliar Rupiah, maka angka harapan hidup akan bertambah sebesar 0.000718 , cateris paribus. Variabel TotMis menunjukkan bahwa setiap ada kenaikan seribu masyarakat miskin di daerah kabupaten kota di Jawa Barat akan menurunkan angka harapan hidup sebesar 0.003713 , cateris paribus. Dengan menggunakan teknik Fixed Effects Model, kita mendapatkan bahwa anggaran kesehatan dan total kemiskinan berpengaruh signifikan terhadap angka harapan hidup. Standar error pada Model Fixed Effects Model telah di robust sehingga terhindar dari masalah heteroskedastisitas. F stat pada regresi Fixed Effects Model adalah sebesar 7.39 dan nilainya signifikan. $\mathrm{R}^{2}$ pada regresi Fixed Effects Model adalah sebesar 0.1484 yang menunjukkan angka harapan hidup dipengaruhi variabel anggaran kesehatan dan variabel total kemiskinan dapat menjelaskan sebesar $14,84 \%$ sedangkan sisanya $85.16 \%$ dipengaruhi faktor diluar model regresi.

c. Random Effects Model

\section{$\mathrm{AHP}=71.46158+0.004677$ AngKes -0.009914 TotMis}

Regresi menggunakan Random Effects Model menunjukkan bahwa setiap anggaran kesehatan meningkat sebesar 1 Miliar Rupiah, maka angka harapan hidup akan bertambah sebesar 0.004677 , cateris paribus. Variabel TotMis menunjukkan bahwa setiap ada kenaikan seribu masyarakat miskin di daerah kabupaten kota di Jawa Barat akan menurunkan angka harapan hidup sebesar 0.009914, cateris paribus. Dengan menggunakan teknik Random Effects Model, kita mendapatkan bahwa anggaran kesehatan dan total kemiskinan berpengaruh signifikan terhadap angka harapan hidup. Regresi pada Random Effects Model sudah menggunakan generalized least squares sehingga model terhindar dari masalah heteroskedastisitas dan autokorelasi.

\subsection{Pembahasan}

Anggaran kesehatan menjadi hal yang sangat penting bagi pembangunan di semua pemerintahan, baik pemerintah daerah maupun pemerintah pusat. Pada tahun 2015 terdapat banyak daerah yang meningkatkan anggaran kesehatan. Terdapat 25 kabupaten kota yang meningkatkan anggaran kesehatan, hanya ada 2 kabupaten kota yang memiliki penurunan anggaran yaitu Kabupaten Bekasi dan Kota Bekasi. Kondisi anggaran kesehatan tahun 2016 tidak lebih baik, terdapat 7 pemerintah kabupaten kota yang memutuskan untuk menurunkan anggaran kesehatan. Pada tahun 2016, rata-rata kenaikan anggaran kesehatan pemerintah kabupaten kota di Jawa Barat adalah sekitar 7\%. Peningkatan ini tetap menjadi hal yang positif karena akan berpengaruh pada kualitas pelayanan kesehatan kabupaten kota di Jawa Barat.

Gambar 4 Menunjukkan bawah peningkatan anggaran kesehatan memiliki pengaruh terhadap kualitas kesehatan masyarakat kabupaten kota di Jawa Barat. Hasil 
regresi ketiga teknik metode Data Panel menunjukkan bahwa ketiga teknik Pooled OLS, Fixed Effects Model, Random Effects Model menunjukkan bahwa anggaran kesehatan berpengaruh positif dan signifikan terhadap angka harapan hidup (AHP). Hasil penelitian ini sesuai dengan penelitian sebelumnya (Arthur \& Oaikhenan, 2017).Pada tahun 2015 dan tahun 2016 semua daerah kabupaten kota di Jawa Barat memiliki peningkatan angka harapan hidup. Pada tahun 2015, peningkatan angka harapan hidup paling tinggi didapatkan oleh kabupaten Tasikmalaya dengan peningkatan sebesar $0.59 \%$ atau sebesar 0.4 tahun dan paling rendah didapatkan Kabupaten Bekasi sebesar $0.03 \%$ atau sebesar 0.02 tahun. Rata-rata peningkatan angka harapan hidup di seluruh kabupaten kota di Jawa Barat pada tahun 2015 adalah sebesar $0.28 \%$ atau sebesar 0.2 tahun.

\section{Gambar 4. Hubungan Anggaran Kesehatan dan Total Penduduk Miskin dengan Angka Harapan Hidup Kabupaten Kota di Jawa Barat}
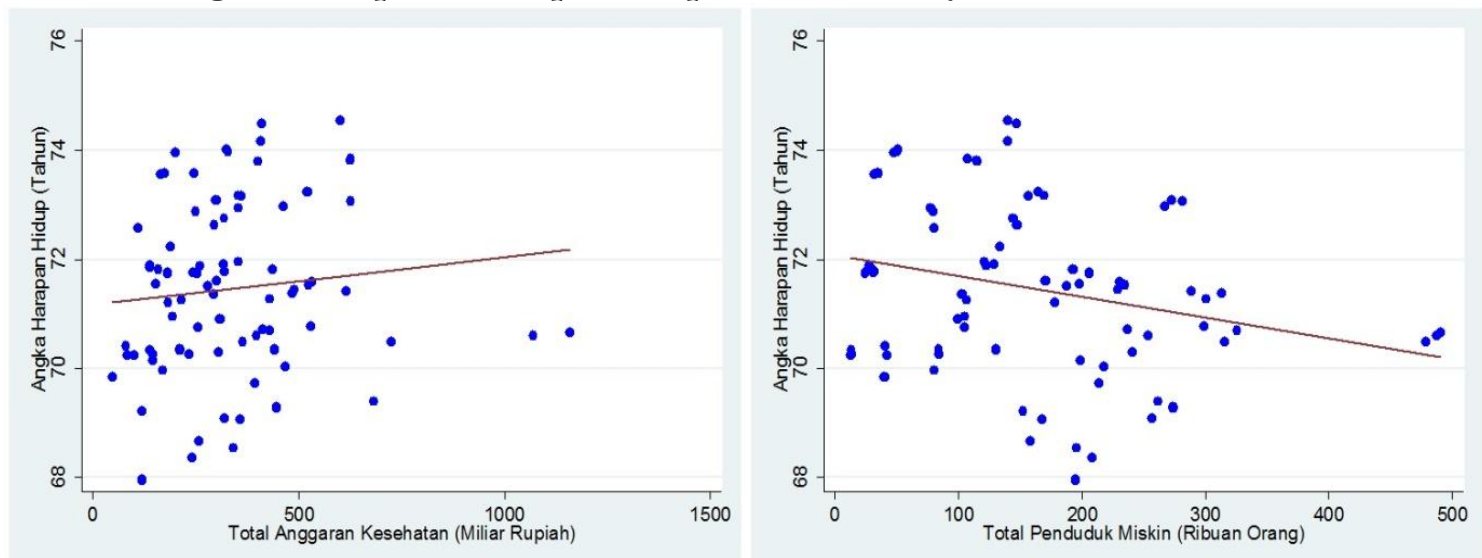

Sumber : Pengolahan Stata, 2019

Pada tahun 2016, peningkatan terbesar tetap didapatkan kabupaten Tasikmalaya. Tetapi peningkatannya menurun dibandingkan tahun 2015 dengan peningkatan sebesar $0.26 \%$ atau 0.18 tahun. Peningkatan terendah didapatkan oleh Kota Cimahi dengan peningkatan sebesar $0.01 \%$ atau 0.01 tahun. Rata-rata peningkatan angka harapan hidup di seluruh kabupaten kota di Jawa Barat pada tahun 2016 hanya sebesar $0.11 \%$ atau sebesar 0.08 tahun. Peningkatan angka harapan hidup tahun 2016 sebesar $0.11 \%$ lebih rendah dibandingkan peningkatan tahun 2015 sebesar $0.28 \%$. Hal ini dapat dipengaruhi kondisi lebih banyaknya pemerintah kabupaten kota yang menurunkan anggaran kesehatan pada tahun 2016 di bandingkan tahun 2015.

Total kemiskinan pada regresi yang telah di lakukan menggunakan ketiga teknik Pooled OLS, Fixed Effects Model, Random Effects Model berpengaruh negatif terhadap angka harapan hidup kabupaten kota di Jawa Barat dan juga ditunjukkan hubungan pada gambar 4. Penelitian ini didukung penelitian yang dilakukan sebelumnya (Torpy et al., 2007). Tetapi hanya Pooled OLS dan Random Effects Model yang menunjukkan bahwa total kemiskinan memiliki pengaruh yang signifikan pada angka harapan hidup. Dari tahun 2014 ke tahun 2016, terdapat penurunan angka kemiskinan di Jawa Barat. Rata-rata angka kemiskinan turun sebesar $0.42 \%$ atau 7.8 ribu orang. Penurunan 
angka kemiskinan ini dapat memberikan pengaruh baik pada peningkatan angka harapan hidup di tahun 2016 di kabupaten kota di Jawa Barat.

\section{PENUTUP}

Angka harapan hidup (AHP) menjadi indikator yang digunakan sebagai indikator kesuksesan pembangunan kesehatan di daerah. Karena itu pemerintah daerah berusaha melakukan berbagai cara untuk melakukan pembangunan sektor kesehatan yang optimal. Salah satu cara nya adalah dengan meningkatkan anggaran belanja kesehatan pemerintah. Regresi dengan menggunakan model Data Panel dengan tiga pendekatan Pooled OLS, Fixed Effects Model, Random Effects Model menunjukkan anggaran kesehatan berpengaruh positif dan signifikan pada peningkatan angka harapan hidup di kabupaten kota di Provinsi Jawa Barat. Teknik Pooled OLS dan Random Effects Model juga menunjukkan bahwa angka kemiskinan berpengaruh negatif dan signifikan pada angka harapan hidup kabupaten kota di Provinsi Jawa Barat. Penelitin ini dapat menjadi rekomendasi kepada pemerintah kabupaten kota di Provinsi Jawa Barat untuk berusaha meningkatkan anggaran kesehatan dan menurunkan angka kemiskinan dari tahun ke tahun. Dengan tinggi nya anggaran kesehatan dan rendahnya angka kemiskinan akan menghasilkan angka harapan hidup yang maksimal di seluruh kabupaten kota di Provinsi Jawa Barat. Angka Harapan Hidup (AHP) yang tinggi menunjukkan pemerintah daerah telah berhasil melakukan pembangunan maksimal di bidang kesehatan.

\section{DAFTAR PUSTAKA}

Akca, N., Sönmez, S., \& Yılmaz, A. (2017). Determinants of health expenditure in OECD countries: A decision tree model. Pakistan Journal of Medical Sciences, 33(6), 1490-1494. https://doi.org/10.12669/pjms.336.13300

Arora, S. (2002). Health, human productivity, and long-term economic growth. The Journal of Economic History, 61(3), 699-749.

Arthur, E., \& Oaikhenan, H. E. (2017). The Effects of Health Expenditure on Health Outcomes in Sub-Saharan Africa (SSA). African Development Review, 29(3), 524536. https://doi.org/10.1111/1467-8268.12287

Bloom David, \& Canning, D. (2008). Population Health and Economic Growth. Health and growth,

Borghini, A., Silenzi, A., Frisicale, E. M., Capelli, G., Tumbarello, G., Parente, P., ... Miraglia, L. (2017). Analysis on health expenditure and correlation with perceived health status in 8 Countries: Daniele Ignazio La Milia. European Journal of Public Health, 27(suppl_3). https://doi.org/10.1093/eurpub/ckx186.117

Boussalem, F., Boussalem, Z., \& Taiba, A. (2014). The Relationship between public spending on health and economic growth in Algeria : Testing for Co-integration and Causality. International Journal of Business and Management, 2(3), 25-39.

Boyacioglu, E. Z. (2012). The importance of health expenditures on sustainable development. International Journal of Social Sciences and Humanity Studies, 4(2), 147 158. 
BPS Jawa Barat. (2017). Umur Harapan Hidup saat Lahir (UHH) Provinsi Jawa Barat 2010-2017. Badan Pusat Statistik. https://doi.org/10.1371/journal.pone.0144713 Dewi, S. (2017). Pemanfaatan Pembiayaan Dalam Sistem Kesehatan di Indonesia. Jurnal Kebijakan Kesehatan Indonesia, 6(3).

Directorate General of Fiscal Balance of Indonesia. (2016). APBD, Realisasi APBD, dan Neraca. Jakarta.

Farag, M., Nandakumar, A. K., Wallack, S., Hodgkin, D., Gaumer, G., \& Erbil, C. (2013). Health expenditures, health outcomes and the role of good governance. International Journal of Health Care Finance and Economics, 13(1), 33-52. https://doi.org/10.1007/s10754-012-9120-3

Greene, W. W. H. . (2012). Econometric Analysis 7th Edition. Prentice Hall. https://doi.org/10.1198/jasa.2002.s458

Gujarati, D. (2003). Basic Econometrics. 4th. ... Econometrics.

Gupta, R. P.-S., de Wit, M. L., \& McKeown, D. (2007). The impact of poverty on the current and future health status of children. Paediatrics $\mathcal{E}$ Child Health, 12(8), 667 672.

Harmana, T., \& Adisasmito, W. B. (2006). Faktor-fakor yang Mempengaruhi Pembiayaan Kesehatan Daerah Bersumber APBD Tahun 2006. Manajemen Pelayanan Kesehatan, 09(03), 134-145.

Jaba, E., Balan, C. B., \& Robu, I.-B. (2014). The Relationship between Life Expectancy at Birth and Health Expenditures Estimated by a Cross-country and Time-series Analysis. Procedia Economics and Finance, Volume 15, 108-114. https://doi.org/10.1016/s2212-5671(14)00454-7

Lakshminarayanan, S. (2011). Role of government in public health: Current scenario in India and future scope. Journal of Family and Community Medicine, 18(1), 26-30. https://doi.org/10.4103/1319-1683.78635

Musgrove, P. (1993). Relations Between Health and Development. Bol Oficina Sanit Panam, 114(2), 115-129.

Ngoma, C. (2017). The Negative Impact of Poverty on the Health of Women and Children. Ann Med Health Sci Res.

Piabuo, S. M., \& Tieguhong, J. C. (2017). Health expenditure and economic growth a review of the literature and an analysis between the economic community for central African states (CEMAC) and selected African countries. Health Economics Review, 7(23). https://doi.org/10.1186/s13561-017-0159-1

Puron-cid, J. R. G. G. (2014). Using Panel Data Techniques for Social Science Research : an Illustrative Case and Some Guidelines. CIENCIAS SOCIALES, 21(3), 203-216.

Sghari, M. B. A., \& Hammami, P. S. (2016). The Relationship Between Life Expectancy and Health Spending. International Journal of Development and Economic Sustainability, 4(6), 45-53.

Taylor, C. E., Newman, J. S., \& Kelly, N. U. (1976). Interactions between Health and Population. Studies in Family Planning, 7(4), 94-100. https://doi.org/10.2307/1965041 
Torpy, J. M., Lynm, C., \& Glass, R. M. (2007). Poverty and Health. JAMA, 298(16), 1968. https://doi.org/10.1001/jama.298.16.1968

Wang, F. (2015). More health expenditure, better economic performance? Empirical evidence from OECD countries. Inquiry (United States), Vol 2015, 1-5. https://doi.org/10.1177/0046958015602666 